\title{
O TV Escola no Município de Irecê - Bahia: fatores que operam como facilitadores e/ou obstáculos a sua plena utilização
}

RESUMO: O presente artigo discute resultados de uma pesquisa de mestrado sobre uso do Programa TV Escola na Rede Municipal de Educação de Irecê, na Bahia. O estudo permitiu conhecer sua infra-estrutura, as práticas pedagógicas dos professores com o kit tecnológico, e os fatores que operam como facilitadores e /ou obstáculos à sua plena utilização nas escolas do município. Apresenta ainda breve revisão de literatura de outras pesquisas realizadas sobre a temática no país. Conclusões demonstraram a necessidade de reavaliação das políticas que norteiam estes programas, principalmente a compreensão de "modernização da escola pública brasileira" através de ênfase na instrumentalização sem que se desenvolvam outros elementos fundamentais como a capacitação dos professores e manutenção destes programas para que essas políticas funcionem como fator de inclusão socioeducacional, e fortaleça a escola pública.

PALAVRAS-CHAVE: Programa TV Escola. Educação e Estado. Prática pedagógica.

\section{Introdução}

O Programa TV Escola constitui-se num conjunto de ações midiáticas, com uso da TV, vídeo e material impresso, destinado à capacitação docente e enriquecimento do processo educativo dos alunos do ensino fundamental e ensino médio. O ponto de partida do Programa, lançado no Brasil em 1996 pela Secretaria de Educação a Distância (SEED/MEC), foi o envio de um conjunto de equipamentos, para escolas públicas com mais de 100 alunos, denominado kit tecnológico, composto por televisor, videocassete, antena parabólica, receptor de satélite e dez fitas de vídeo VHS para iniciar a gravação dos programas veiculados. Sua programação é transmitida via Satélite de Comunicação BrasilsatI e transmitidos para todo país em canal aberto. Os vídeos abrangem as áreas disciplinares e transversais dos níveis fundamental e médio, de acordo com os Parâmetros Curriculares Nacionais do Ensino Fundamental e Médio, e programas do Salto para o Futuro, produzidos pela TV Brasil, destinados à formação continuada de professores.
Telma Brito Rocha Doutoranda em Educação FACED/ UFBA

Professora Substituta UEFS telmabr@ufba.br 
(1) Acesso ao site http:// portal.mec.gov.br/seed/ index. php?option $=$ content $\&$ task $=$ view\&id =69\&ltemid $=199$ em 09/04/007.

Segundo o Censo (SEED) de 2003, existem 60.955 escolas públicas com mais de 100 alunos. Nessas escolas, estudam 28965 896 alunos e trabalham 1091661 professores. A Secretaria de Educação a Distância (SEED) ${ }^{1}$ informa que o TV Escola está em 39 634 do total dessas escolas, o que representa 65\% da Rede Pública Brasileira. O Programa ainda está presente em 221 núcleos de tecnologias educacionais, onde são desenvolvidas as atividades de capacitação de professores e técnicos de suporte, e desenvolvimento de pesquisas, em 200 agências do Proformação e 116 em universidades públicas que formam professores.

Em Irecê, das 30 escolas de sua Rede Municipal, apenas quatro, todas localizadas na zona urbana, não possuem o kit, três dessas escolas atendem apenas a educação infantil, portanto não se enquadram no critério de participação que é oferecer ensino fundamental, e uma outra escola teve o kit tecnológico roubado. É importante esclarecer que desse total de escolas, 19 estão situadas na sede do município e 11 na zona rural.

Nessa rede de ensino, em 2004, período em que a pesquisa foi realizada, existiam 480 trabalhadores ligados aos setores administrativos da secretaria de educação, na docência e gestão escolar. Do total de alunos matriculados em seu sistema de ensino, tinham 4285 alunos que estão matriculados nos dois ciclos iniciais, 3012 matriculados nos $3^{\circ}$ e $4^{\circ}$ ciclos 1464 alunos matriculados na Educação de Jovens e Adultos ( $1^{\circ}$ e $2^{\circ}$ segmentos), 666 alunos na educação infantil.

A pesquisa ora relatada teve duas etapas: A primeira de ordem quantitativa foi executada em todas as 30 escolas da Rede, no período de março a maio de 2004, através da aplicação de questionários destinados aos gestores escolares, professores e coordenadores. Desse universo, 228 professores, 30 coordenadores e 30 diretores participaram da pesquisa, representando $60 \%$ dos trabalhadores da Rede Municipal de Educação. Neste momento, foi levantada a infra-estrutura tecnológica e os indicadores de utilização.

A segunda etapa foi realizada no mês de agosto, setembro e outubro de 2004 a partir de um estudo de caso de três escolas, duas localizadas na zona urbana e uma na zona rural. O critério de escolha tentou atingir a amplitude da Rede, observando suas características e singularidades. A primeira delas foi escolhida porque está situada num bairro periférico da cidade, onde as con- 
dições socioeconômicas dos alunos são bastante precárias, assim como as condições de infra-estrutura da escola. A segunda foi escolhida pelo potencial tecnológico, o que a diferencia das demais, já que possui internet via rádio, um sistema interno de comunicação amplificado, dispõe de antena analógica e digital do Programa, e conta com quatro televisores e quatro vídeos. Estas duas escolas atendem da Educação Infantil ao Ensino Fundamental das séries iniciais. A terceira foi escolhida por atender prioritariamente ao Ensino Fundamental de $5^{\mathrm{a}}$ a $8^{\mathrm{a}}$ série e está situada na zona rural do Município.

Essa descrição mostrou as implicações que perpassam o fazer pedagógico dos professores com o Programa e a política de modo geral. Foi escolhido esse caminho, por entender que

[...] a estrutura de um estudo de caso deve ser composta, pelo menos em três dimensões: a institucional ou organizacional, a instrucional ou pedagógica e a sociopolitica/cultural. Para ela essas três dimensões não podem ser consideradas isoladamente, mas como uma unidade de múltiplas inter-relações, através das quais se procura compreender a dinâmica social expressa no cotidiano escolar. (ANDRÉ, 1995, p.42).

\section{Infra-estrutura do programa na rede municipal de educação de Irecê}

A cobertura do kit tecnológico na Rede Municipal de Irecê não se constitui em obstáculo à falta de utilização da programação do TV Escola. Ao contrário do que demonstram as pesquisas no país, algumas levantadas a seguir, os problemas técnicos nos aparelhos e a falta de manutenção não operam como uns dos principais fatores para não se utilizar os kits e a recepção da programação.

Os dados nos revelaram que 91\% do total de televisores do Programa nas escolas estão em bom funcionamento, um número significativo para um Programa que possuía sete anos de implantação no momento da pesquisa. No caso do vídeo o percentual é um pouco menor: 88\% desses equipamentos estão em bom funcionamento.

Análises revelaram que o obstáculo principal quanto à utilização do TV Escola está relacionado à falta de utilização da programação veiculada no canal educativo. Dos 228 professores que 
fizeram parte da pesquisa, apenas 3\% assistem à programação, e nenhum deles, realizam gravações.

Durante a pesquisa foi identificada várias questões que impedem a utilização da programação do TV Escola. O mais interessante é que a principal dificuldade não está no âmbito da operação dos equipamentos como ligar, desligar, utilizar as funções do vídeo, ou conectar o receptor, ou a falta de acesso aos equipamentos. Esta questão aparece como uma das últimas dificuldades enfrentadas pelos docentes. Do total de entrevistados, apenas $5 \%$ da zona urbana e $10 \%$ da zona rural não sabem operar os equipamentos. Os professores em sua maioria sabem ligar e desligar o televisor e o vídeo, assim como utilizar as funções deste último, retroceder, avançar, parar a programação de uma fita VHS. A seguir, o relato de uma professora nos comprova que

A coisa da dificuldade com a operação é coisa do passado, realmente quando os kits chegaram a mais ou menos 5, 6 anos a maioria dos professores não tinham em casa, não era uma coisa habitual e corriqueira que você estava fazendo uso, como os computadores. Hoje ninguém tem problema para ligar e desligar o vídeo cassete, ou adiantar uma fita, ninguém tem problema com isso mais não. (Professora do Ensino Fundamental - $3^{\circ}$ ciclo)

Portanto, se os professores não possuíam dificuldades quanto ao manuseio dos equipamentos, que fatores contribuíam para a não utilização da programação veiculada e sua gravação para formação da videoteca na escola?

Em visitas às escolas onde estavam os 3\% dos professores que assistiam ao Programa, foram realizadas entrevistas semiestruturadas, e encontramos os motivos que levam à falta de gravação. Entre eles está a ausência de recursos para a compra de fitas VHS. Os gestores educacionais acrescentaram que a verba anual do PDDE não consegue garantir os materiais de consumo mais comuns para os professores ministrarem suas aulas durante o ano letivo e, por considerarem a aquisição da fita de vídeo como um recurso muito caro, não podem privilegiar esse material em detrimento de outros como o giz, o estêncil, o papel ofício, prioritários no contexto da educação do município.

Outro dado que contribui para esse pouco acesso à programação são as questões ligadas a infra-estrutura da escola; isso impede que a comunidade escolar encontre um espaço adequado 
para que possam agregar as atividades de docência e capacitação no uso do TV Escola. Por este motivo, temos 52\% desses equipamentos, televisor e vídeo desconectados do receptor.

Por outro lado, os 48\% de escolas que possuem entre um, dois ou três televisores conectados ao receptor também não fazem uso da programação com os alunos, porque ficam instalados em diversos setores da escola, como secretaria, sala da direção, sala de coordenação, sala dos professores, espaços inapropriados para as sessões de vídeos com os alunos.

Observa-se que a falta de um espaço como uma sala/auditório, ou um sistema de cabeamento que leve um ponto de recepção a cada sala de aula, se constitui num fator muito relevante para a não utilização da programação do TV Escola na educação. O depoimento da professora abaixo revela a questão:

\begin{abstract}
A locomoção da TV e do vídeo dificulta a gente usar. Se a gente tivesse um suporte na nossa sala, ou um espaço para ir com a turma ia ser bem mais fácil. O governo às vezes investe, mas joga dinheiro fora. Eu acho que ele não pensa nas outras questões, aí paga caro por isso. Se tivesse dado uma verba para criar um espaço seria bem mais utilizado. (Professora do ensino fundamental - $2^{\circ}$ ciclo)
\end{abstract}

Outro fator que contribui para a não utilização do TV Escola é a falta de inclusão dos temas veiculados na programação dos planejamentos pedagógicos dos professores. Registramos um total de $26 \%$ dos professores da zona urbana e 28\% da zona rural que atribuíram isso ao fato de não usarem a programação em suas aulas.

A falta de preparação pedagógica para trabalhar com o TV Escola é também outro dado apontado como dificuldade na utilização da programação. Em Irecê, a maioria dos 228 professores entrevistados, nunca havia participado de curso de capacitação sobre o TV Escola promovido pelo governo federal, estadual ou municipal.

Perguntados sobre a possibilidade de incluir no seu planejamento vídeos do TV Escola, durante os encontros semanais de coordenação pedagógica, professores e coordenadores responderam que a demanda em relação ao planejamento das disciplinas é grande, assim como para elaboração das aulas semanais, não é possível, segundo eles, existir tempo para estudar, nem as- 
sistir a um vídeo de capacitação docente do programa Salto para o Futuro veiculado pelo canal. Para Belloni (2002, p.18),

Os problemas relacionados com o tempo são fundamentais em EaD, não apenas em suas dimensões física, institucional e imaginária, que formam a base das relações temporais concebidas por cada indivíduo e estabelecidas na sociedade, mas também em sua dimensão econômica, de medida do tempo de trabalho, definidora das condições de trabalho e de formação dos trabalhadores. A ausência de um tempo para a formação continuada, previsto especificamente para este fim, dentro da jornada de trabalho dos professores, é provavelmente a causa principal da baixa efetividade do Programa.

\section{Revisando as pesquisas sobre o tema}

Analisando a literatura sobre a temática, no país, percebe-se que alguns dos obstáculos enfrentados em Irecê são semelhantes aos de outras regiões. Em Santa Catarina, Belloni (2004) constatou que, das 134 escolas estaduais e municipais pesquisadas na grande Florianópolis, 40\% estavam com problemas técnicos nos kits tecnológicos. Essa precariedade técnica, segundo a autora, se distribui de modo mais ou menos igualitário nas duas Redes públicas. Das 82 escolas estaduais pesquisadas, em 38\% delas o kit tecnológico não estava funcionando. Nas 42 escolas da Rede municipal esse percentual é um pouco maior. Em 45\% delas o quadro era o mesmo.

Outro dado relevante identificado pela autora é a falta de uma infra-estrutura mínima que assegure aos professores condições para recepção do TV Escola. Não existem salas estruturadas para exibição dos vídeos, nem espaço reservado para estudo dos professores, o que demonstra que as formas arquitetônicas das escolas no país precisam ser repensadas, adaptadas às novas demandas espaciais de aprendizagem.

A pesquisa realizada por Cláudia Guerra Monteiro através do Programa de Pós- Graduação da Universidade Metodista de São Paulo, intitulada Cidadão VHS: a aventura da TV Escola em Manaus, e que implicou um trabalho de campo em 94 escolas de ensino fundamental em Manaus, revelou que, do total de escolas visitadas, a maioria convive com fitas mofadas, em função do clima quente e úmido da região. Como as escolas só recebem 
o kit e não há nenhum treinamento, nem material disponível para a manutenção das fitas, o clima tropical amazônico reduz significativamente o tempo de uso dos vídeos. Existem escolas que perderam todo o estoque de fitas gravadas.(MONTEIRO 1998, p. 13)

A autora acrescenta ainda que o serviço de segurança patrimonial é precário, muitos kits foram roubados, e nem sempre as escolas recebem novos kits para substituição. Isto nos revela que o TV Escola precisa repensar sua estrutura de funcionamento para os diferentes estados brasileiros. É necessário que as políticas possam atender essas diversidades, com financiamento para investimento em manutenção do Programa.

Os problemas relacionados à arquitetura escolar e à infraestrutura dos locais onde ficam instalados os equipamentos são sempre apontados nessas pesquisas. No caso de Manaus, a autora acrescenta que as salas em que são exibidos os programas do TV Escola são pequenas para o número excessivo de alunos: deveriam abrigar 30 alunos, mas geralmente abrigam 60, por conta da falta de salas de aula que possam atender à demanda de alunos na Rede de ensino. Por esse motivo, o televisor de 14 polegadas é inapropriado para tal trabalho, já que os alunos ficam impossibilitados de enxergar a tela.

Em vista disso, podemos identificar os entraves de uma política hegemônica para diferentes regiões, com diferentes realidades educacionais. O Programa não atende a esses estados com financiamento para implementar o funcionamento do TV Escola em melhores condições, adequando-o ao contexto em que estão inseridos.

Em pesquisa sobre o Salto para o Futuro no Distrito Federal, em 1997, a autora Elizabeth Danziato Rego Lima da Universidade de Brasília também revelou semelhantes problemas que dificultam o funcionamento da proposta de capacitação dos professores. Torna-se importante ressaltar que esta pesquisa foi uma das primeiras sobre o tema, realizou-se um ano após implantação do TV Escola. Portanto, várias contribuições sobre o seu funcionamento do Programa nos estados do Brasil já eram emitidas; no entanto, não estamos verificando mudanças significativas no âmbito da política do Ministério.

Entre as principais questões levantadas pela autora na época, estavam a inexistência de infra-estrutura adequada aos 
telepostos e as telesalas onde aconteciam a recepção da programação; Impossibilidade da equipe de produção do programa realizar visitas aos telepostos brasileiros. Este aspecto, para a autora, é de grande importância, pois colocava a referida equipe distante do professor. A falta de preparo técnico da equipe, que ela já apontava em 1997 como um dos aspectos mais sérios em relação ao próprio futuro do programa Um Salto para o Futuro, mostra a urgência de se oportunizar a capacitação do pessoal envolvido com a recepção do Salto na Capital. Outro aspecto é a falta de orientação ao telealuno com relação às características metodológicas do programa. Ficou evidenciado, em seu estudo, que os telealunos não identificavam o programa como sendo realizado por metodologia a distância, desconheciam suas características principais.

No caso dos projetos de educação a distância, essa dificuldade se expressa ainda mais em virtude da falta de acesso de nossa população às tecnologias de informação e comunicação de modo pleno, ou seja, a falta de acesso à internet para que o professor possa conhecer diferentes formas de produção de conhecimento e possam estabelecer redes cooperativas para explorar esses projetos. Em Irecê, do total dos 228 professores pesquisados, apenas 2\% deles possuem correio eletrônico.

Políticas que visem apenas à introdução de equipamentos na escola, sem viabilizar a conexão à rede internet, sem articulação dos diferentes programas, deixando ainda em segundo plano planejamento e execução, sem acompanhamento, avaliação e intervenções para potencializar estes projetos, sempre incidirão nos desencontros que essas pesquisas nos revelam. Para Picanço (2001, p.30),

De certa forma, não existe um desenvolvimento estratégico na área, envolvendo as ações, políticas e as reflexões teóricas que vêm acompanhando todo o percurso da EaD. Esse encaminhamento criaria condições para um outro projeto político de sociedade no qual a idéia de democratização que é imputada à EaD poderia ser, permanentemente, construída no dialogo entre os diferentes atores sociais e suas necessidades, definindo objetivos explícitos e compartilhados. 


\section{Professoras(es): suas práticas com o kit tecnológico}

Embora o TV Escola não esteja funcionando como um projeto organizado de forma coletiva, e nem exista aproveitamento de sua programação veiculada, cada docente utiliza o kit tecnológico de forma independente, $86 \%$ dos professores fazem uso do televisor e vídeo. As sessões de filmes comerciais estão entre as principais atividades que esses professores realizam.

Os vídeos mais utilizados entre os professores são os filmes de longa metragem, locados na sua maioria com recursos próprios em lojas da cidade. Alguns desses profissionais desconhecem que a secretaria assume o custo da locação, outros consideram que esse contrato é limitante, pois como só podem locar num único espaço designado pela secretaria, isso restringe a oferta de filmes.

As disciplinas mais trabalhadas com o vídeo são geografia, história e ciências no ensino fundamental, nas séries de $5^{\mathrm{a}}$ a $8^{\mathrm{a}} \mathrm{e}$ nas séries iniciais $1^{\mathrm{a}}$ a $4^{\mathrm{a}}$; e neste último caso, quando atendem concomitantemente à educação infantil, os professores fazem uso intensivo de filmes clássicos infantis.

Na educação infantil, três dos professores de uma escola deste nível de ensino, costumam trabalhar com filmes infantis comerciais, geralmente trabalham associando o vídeo com o texto escrito das estórias infantis dos livros clássicos. Essas sessões de filmes são trabalhadas após a leitura dos contos infantis. Aqui, a narrativa cinematográfica tem a função de ilustrar as histórias narradas pelos professores.

Apesar deste nível de ensino possibilitar o exercício da capacidade de criatividade, o uso do vídeo é encarado como uma atividade que deve atender ao pré-requisito de se ter inicialmente o contato com o texto escrito para depois partir para a imagem posta na narrativa cinematográfica. Aqui, o vídeo é tratado de forma seqüenciada, por etapas que prevalecem à primazia da linguagem escrita; ele tem função apenas de reforçar o conteúdo programático posto anteriormente. Uma perspectiva linear de trabalho que fragmenta os saberes, com atividades pedagógicas funcionando como etapas, degraus. Segundo Ramal (2002, p.184), esse modelo

[...] de escada não nos serve mais, pois deriva de pressupostos epistemológicos impostos por pela cultura da palavra impressa. A sala de 
aula monológica e limitada à sua voz única é questionada pelos novos perfis cognitivos que se organizam a partir da abertura de múltiplas janelas, possibilidade natural da mente humana que é potencializada pela hipertextualidade $[\ldots]$

Uma dimensão seqüenciada para se trabalhar as linguagens na escola, mesmo que esses alunos fora dela convivam concomitantemente com ambas, embora saibamos ainda que no caso da linguagem da televisão e de outras mídias, esse convívio se dê muito mais em tempo e interesse do que os textos escolares.

Não existem projetos com o vídeo que integrem diversas disciplinas do currículo escolar no ensino fundamental. Eles são trabalhados de modo isolado até entre os professores da mesma série ou numa mesma disciplina na escola. O conhecimento ainda é interpretado numa visão muito disciplinar. Os professores alegam que sentem dificuldade de realizar um trabalho multidisciplinar ou interdisciplinar, integrando geografia, matemática e artes no trabalho com o vídeo. Em geral, eles associam apenas a questão trabalhada naquele contexto de sua disciplina.

Entre os seis docentes entrevistados na segunda etapa da pesquisa, ainda que relacionem a temática dos filmes com o tema da aula, a potencialidade dessa tecnologia é limitada quando tratam esses vídeos apenas como fonte de ilustração do que vem sendo trabalhado numa aula expositiva, migrando os velhos conceitos expressos nos tradicionais planos de aula, que consideravam essas tecnologias como um recurso didático / motivador da aprendizagem. Nesse sentido, essas tecnologias são muitas vezes consideradas como

[...] uma natural evolução, às vezes até brusca, dos velhos projetores de slides, retroprojetores ou mesmo, dos conhecidos e analisados livros didáticos. Em síntese, busca-se a utilidade destes novos equipamentos com uma evidente redução das possibilidades do seu uso. (PRETTO, 1994, p. 101)

A utilização do vídeo numa perspectiva apenas transmissiva também foi observada entre a prática de professores. O conteúdo presente na narrativa desse vídeo não é problematizado ao final de sua exposição na turma, ele é resumido em um questio- 
nário fechado onde todos deverão responder de forma igual. Conseqüentemente, a avaliação aqui funciona de forma homogênea, pois a resposta "certa" já foi elaborada pelo professor, e todos devem responder o que ele espera; caso contrário, a resposta do aluno não tem validade. Essa prática acaba abortando a capacidade criativa do aluno. Por isso, de forma geral, os trabalhos com a mídia na escola, acabam

[...] formatando esses meios de acordo com as características da escola atual: a centralidade de conteúdos, a fragmentação e a linearidade do conhecimento, a superficialidade com que são tratadas as questões que dizem respeito à vida cotidiana dos alunos, a não problematização dos próprios meios de comunicação. (BONILLA, 2002, p.122).

Neste caso, o vídeo vem apenas substituir a aula do professor, de modo absoluto, sem que os alunos possam realizar intervenções sobre as informações postas ali, opiniões que possibilitem a ressignificação dessas informações e, conseqüentemente, a construção de conhecimento. O vídeo aqui tem a função de perpetuar o modo transmissivo da velha educação tradicional. Não existe uma prática pedagógica mais interativa onde o professor "[...] cria possibilidades de envolvimento, oferece ocasião de engendramentos, de agenciamentos" (SILVA, 2000, p. 73), possibilitando a participação dos alunos como autores de novos conhecimentos a partir do que se assistiu e discutiu em sala de aula.

Paulo Freire, em Pedagogia do oprimido, discutindo a perspectiva dialógica da educação nos chamava a atenção para aquilo que ao meu ver é imprescindível ao âmbito da prática educativa e ao trabalho com mídia na escola de modo geral. A construção de uma educação dialógica, onde os atores educativos possam expressar diferentes interpretações sobre o objeto estudado, realizando uma educação mais problematizadora, crítico-reflexiva. Para Freire (1994, p. 108),

Na linha do emprego destes recursos, parece-nos indispensável a análise do conteúdo dos editoriais da imprensa, a propósito de um mesmo acontecimento. Por que razão os jornais se manifestam de forma diferente sobre um mesmo fato? Que o povo então desenvolva o seu espírito critico para que, ao ler jornais ou ao ouvir o noticiário das emissoras de rádio, o 
faça não como mero paciente, como objeto dos "comunicados" que lhes prescrevem, mas como uma consciência que precisa libertar-se.

Nesse sentido, a educação libertadora, problematizadora já não pode pode ser o ato de depositar, ou de narrar, ou de transferir, ou de transmitir "conhecimentos" e valores aos educandos, meros pacientes, à maneira da educação "bancaria", mas um ato cognoscente. (FREIRE, 1994, p.68)

Outros depoimentos sobre o significado do vídeo para os professores nos revelaram que os filmes são sempre trazidos para o espaço da sala de aula para tornar o conteúdo presente num livro didático mais enriquecedor, motivador. A narrativa cinematográfica, aqui, é separada do contexto textual de modo geral, gerando um profundo [...] desencontro entre o discurso didático-pedagógico escrito e as linguagens institucionalmente não-escolares". (CITTELI, 2001, p.21)

Nesse sentido, os assuntos que circulam na mídia televisiva, de modo geral, não se constituem como assuntos incluídos nos planejamentos pedagógicos; esses temas poderiam expressar conceitos e significados.

\section{Conclusão}

Este estudo revelou os condicionantes que operam como obstáculos ao desenvolvimento de uma política pública de educação em uma rede de ensino. Podemos dizer que as diferenças desse sistema educacional, suas dificuldades, a escassez de recursos, a baixa qualificação docente, põem em evidência muito mais os obstáculos na execução destes programas, do que sucessos dessas políticas. No caso de Irecê, a utilização que se faz do TV Escola é muito individualizada; cada um faz o que está ao seu alcance, do que é possível dentro dos limites de sua realidade escolar, da sua condição docente. O baixo uso e exploração do potencial desses programas respondem igualmente ao baixo nível de qualificação dos professores que fazem uso deles. Por isso, professores e redes de ensino, no país, geralmente se distanciam do que esperam as metas impostas pelas políticas públicas. No caso de Irecê, o TV Escola não responde exatamente ao que deseja o Ministério: a função de capacitação docente, e utilização dos vídeos veiculados 
pelo programa como material didático em sala de aula. Atualmente, o televisor e o vídeo do kit têm sido servidos apenas como um apoio material às atividades do professor em sala de aula.

As questões ligadas à gestão também fazem parte do conjunto de obstáculos. A ausência de um projeto construído pelos professores, coordenadores, diretores e secretaria municipal reduz certamente o desenvolvimento do programa. As justificativas em relação à não existência desse projeto estão ligadas ao excesso de trabalho, à falta de condições materiais para desenvolvimento do programa na rede de ensino. Portanto, um conjunto de questões que as políticas educacionais se omitem a solucionar para que programas dessa natureza possam ser mais aproveitados pelas escolas do país.

Sabemos que sem a vontade política do Ministério, secretarias e escola, o potencial que desejamos explorar das tecnologias para a educação não vai se concretizar. Sem as mudanças no âmbito das práticas pedagógicas, sem uma gestão e manutenção financeira ao programa essas tecnologias vão chegar às escolas, e continuarão em alguns casos, trancadas, sem acesso para alunos e professores, ou sendo utilizadas de modo a reforçar um sistema educacional tradicional baseado na transmissão unívoca do professor.

TV School in the Municipality of Irece - Bahia: factors that act as facilitators and/or obstacles

\begin{abstract}
The present article presents resulted of a research of mestrado on use of Program TV School in the Municipal Net of Education of Irecê in the Bahia. The study it allowed to know its infrastructure, practical the pedagogical ones of the professors with the technological Kit, the factors that operate as facilitadores and / ou obstacles its full use in the schools of the city. It still presents soon revision of literature of other research carried through on the thematic one in the country. Conclusions had demonstrated the necessity of reevaluation of the politics that guide these programs, mainly the understanding of "modernization of the Brazilian public school" through emphasis in the instrumentalização without that if they develop other basic elements as the qualification of the professors and maintenance of these programs so that these politics function as inclusion factor partner educational, and fortify the public school.

KEY WORDS: TV Escola Program.Education and State. Pedagogic practice.
\end{abstract}

\title{
Referências
}

ANDRÉ, Marli Eliza Dalmazo Afonso de. Etnografia da prática escolar. Campinas, SP: Papirus, 1995. 
BELLONI, Maria Luiza. Ensaio sobre a educação a distância no Brasil. Educ. Soc.,v.23, n.78, p.117-142, abr. 2002. Disponível em < http:/ /www.scielo.br > Acesso em: abr 2005.

A televisão como ferramenta pedagógica na formação de professores. Educ. Pesqui., v.29, n.2 p.287-30, jul./dez. 2003. Disponível em <http://www.scielo.br> Acesso em: out. 2004.

BONNILA, Maria Helena Silveira. Escola aprendente: desafios e possibilidades postos no contexto da sociedade do conhecimento. 2002. 304f. Tese (Doutorado em Educação) -Universidade Federal da Bahia, Faculdade de Educação, Salvador.

BRASIL.Secretaria de Educação a Distancia. Conheça a TV Escola. Brasília, [2004]. Disponível em:<http://portal.mec.gov.br/seed/ index.php?option $=$ content\&task $=$ viewEid $=69 \&$ Itemid $=199>$ Acesso em: 09 abr. 2007.

CITELLI, Adilson. Outras linguagens na escola. São Paulo: Cortez, 2001.

FREIRE, Paulo. Pedagogia do oprimido. Rio de Janeiro: Paz e Terra,1994.

LIMA, Elisabeth Danziato Rego. Limites e possibilidades da Educação a Distância: "um salto para o futuro" no Distrito Federal. 1997. 265f. Dissertação (Mestrado em Educação) - Universidade Católica de Brasília, Faculdade de Educação.

MONTEIRO, Claudia Guerra. Cidadão VHS: a aventura da TV Escola em Manaus. São Paulo: 1998. Disponível em:<http:// www.eca.usp.br/nucleos/nce/pdf/030.pdf > . Acesso em: 10 nov. 2004.

PICANÇO, Alessandra de Assis. Educação à distância e outros nós: uma análise das telessalas do telecurso 2000 coordenadas pelo SESI na Bahia. 2001. 136 f. Dissertação (Mestrado em Educação) -Universidade Federal da Bahia, Faculdade de Educação, Salvador.

PRETTO, Nelson De Luca. A universidade e o mundo da comunicação. 1994. 265f. Tese (Doutorado em Ciências da Comunicação) Universidade de São Paulo, Escola de Comunicação e Artes, São Paulo.

RAMAL, Andréa Cecília. Educação na cibercultura: hipertextualidade, leitura, escrita e aprendizagem. Porto Alegre: Artmed, 2002.

ROCHA, Telma Brito Rocha. O Programa TV Escola no município de Irecê: limites e possibilidades da educação a distância no interior do Brasil. 2005. 120 f. Dissertação (Mestrado em Educação) -Universidade Federal da Bahia, Faculdade de Educação, Salvador.

SILVA, Marco. Sala de aula interativa. 3. ed. Rio de Janeiro: Quartel, 2000. 